\title{
Osteosentez başarısızlık ve yetmezliklerinde tedavi kriter ve yöntemleri
}

\section{Treatment criteria and methods in osteosynthesis failure}

\author{
Seçkin Basılgan, Mehmet Özbey Büyükkuşcu \\ İstanbul Gaziosmanpaşa Eğitim ve Araştırma Hastanesi, Ortopedi ve Travmatoloji Kliniği, İstanbul
}

\begin{abstract}
Kalçanın femur boyun ve intertrokanterik bölge kırıklarında kaynamama nadirdir. Ancak kaynamama gelişen hastalar ciddi ağrı ve sakatlık sergiler. Kurtarma tedavisi seçimine kılavuzluk eden faktörler arasında, kaynamamanın anatomik bölgesi, kalan kemik kalitesi, yaş ve aktivite seviyesi yer alır. Kalça eklemi iyi korunmuş genç ve aktif hastalarda tedavi genellikle osteotomi ya da kemik grefti kullanarak veya kullanmadan revizyon ve internal tespittir. Bununla birlikte, yaşlı, sedanter hayat tarzı ve komorbiditeye sahip hastalarda kurtarma seçeneği olarak sıklıkla artroplasti kullanılmaktadır. Kurtarma prosedürleri ile ilgili olarak, karar vermedeki en büyük zorluklar arasında hem kullanılacak implant seçimi hem de ameliyat öncesi doğru planlama yer alır. Kalça artroplastisine karar vermekteki zorluklar ise, asetabular yüzey yenileme ihtiyacı, femoral implantın seçimi ve trokanter major yetmezliğinin yönetilmesidir.
\end{abstract}

Anahtar sözcükler: femur boynu; intertrokanterik; kırı; kaynamama; tespit başarısızlığı; tedavi stratejisi

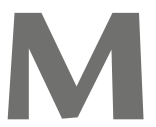

evcut açık redüksiyon ve internal tespit yöntemleri, çoğu kalça kırığının sorunsuz iyileşmesiyle sonuçlanır. Bununla birlikte, çok yaygın görülen kırıklardan biri olduğu için, kaynamama görülen küçük bir yüzde bile önemli sayıda hastayı temsil eder. ${ }^{[1]}$ Kırık tespitinin başarısızlı̆gına katkıda bulunan faktörler arasında istenmeyen kırık paternleri, yetersiz tespit ve kötü kemik kalitesi bulunur. Bu durum hastalarda ciddi şikâyet oluşturur, bu da etkili kurtarmayı önemli kılar. ${ }^{[2]}$ Osteosentez başarısızlığında kurtarma prosedürü olarak çeşitli yöntemler kullanılabilmektedir. Tercih edilecek yöntemi seçerken hasta yaşı, genel durumu, enfeksiyon varlı̆̆ı, femur başı canlılığı ve ilk tespit sonrası geçen süre göz önünde bulundurulması gereken en önemli faktörlerdir. ${ }^{[3]}$

\begin{abstract}
Non-union of fractures about the femoral neck and intertrochanteric hip regions is uncommon. Patients who develop non-unions of these fractures typically exhibit marked pain and disability. Factors that guide the choice of salvage treatment include the anatomic site of the non-union, the quality of the remaining proximal bone and articular surface, patients' age and activity level. In younger patients with a well-preserved hip joint, treatment typically involves revision internal fixation with or without osteotomy or bone grafting. However, arthroplasty is frequently used as a salvage option in the treatment of elderly patients. With respect to salvage procedures for the femoral head, the major challenges in decision making include the choice of both internal fixation device and accurate preoperative planning. The challenges involved in planning to convert to hip arthroplasty include the need for acetabular resurfacing, selecting the femoral implant, and managing discontinuity of the greater trochanter.
\end{abstract}

Key words: femoral neck; intertrochanteric; fracture; non-union; fixation failure; treatment strategy

\section{FEMUR BOYUN KIRIKLARINDA TESPIT YETERSizLiĞi}

Tespit yetersizliği ve kaynamama, ayrılmış ya da ayrılmamış femur boyun kırıklarının tedavisi sonrasında görülen temel yetmezlik biçimidir. Bu iki problemi birbirinden ayırmak güçtür çünkü tespit sonrası çoğu ayrılmış kırığın iyileşmesi uzun zaman alır, bu da tespitin başarısızlığını artırır. Ayrılmamış kırıklarda insidans düşüktür ve tespitin başarısız olması nadir bir komplikasyondur. ${ }^{[4]}$ Her iki komplikasyon da ayrılmış kırıkların redüksiyon ve tespitinden sonra daha sık görülür. Ayrılmış kırıklarda kaynamama ve/veya revizyon gerektiren tespit kusuru oranı \%40'lara kadar varan seviyelerde bildirilmiştir. ${ }^{[5]}$ Sloobegean ve ark., yaptıkları meta-analiz çalışmasında 60 yaşın altındaki hastalarda

\footnotetext{
- İletişim adresi: Uzm. Dr. Seçkin Basılgan, İstanbul Gaziosmanpaşa Eğitim ve Araştırma Hastanesi, Ortopedi ve Travmatoloji Ana Bilim Dalı, İstanbul Tel: 0507 - 2399084 e-posta: dr_seckinbs@yahoo.com 
ayrılmış kırıklarda kaynamama oranını \%9,3, tespit yetersizliğini ise $\% 9,7$ olarak vermişlerdir. ${ }^{[6]}$

Bu problemin teşhisi genellikle basittir çünkü hastalar artan kalça ağrısı, çökme ve redüksiyon kaybına bağlı bacakta kısalma ve tespit başarısızlığının radyolojik dökümantasyonu ile başvururlar. Düz radyografiler şüpheli ise, kemik sintigrafisi genellikle kaynamama alanında artmış aktivite gösterir. Bilgisayarlı tomografi ve manyetik rezonans görüntüleme femur boynundaki kaynamanın durumunu ve femur başının canlıı̆ı̆ını değerlendirmede yardımcı olur. ${ }^{[7]}$ Enfeksiyon potansiyel nedendir ve tüm olgularda akla gelmelidir. Bu nedenle, ameliyat öncesi değerlendirme, eritrosit sedimentasyon hızı ve C-reaktif protein seviyesi ile birlikte tam kan sayımını içermelidir. ${ }^{[8]}$ Bununla birlikte, kaynamama bölgesinin aspirasyonuna rutin olarak gerek yoktur, çünkü hem yeterli bir örnek elde etmek teknik olarak zordur hem de sonuçların güvenilirliği literatürde iyi belgelenmemiştir. Bunun yerine, donmuş kesit (frozen-section) histolojisi için kaynamama bölgesinden ameliyat içi doku örnekleri alınabilir. ${ }^{[8]}$ Enfeksiyon teşhis edildiğinde, artroplasti veya femur başını kurtarma girişiminin planlanıp planlanmadığına bakılmaksızın aşamalı bir yaklaşım tercih edilir. Takip edilecek basamaklar, tüm implantları çıkarmak, derin doku kültürü elde etmek ve tüm nekrotik dokuları debride etmektir. Femur başının enfekte olduğu düşünülürse, Girdlestone rezeksiyonu yapılmalıdır. Enfektif organizmayla savaşmak için uygun antibiyotiklerin kullanımı ameliyat sonrası en az 6 hafta boyunca gereklidir. ${ }^{[8]}$ Ayrıca, ameliyat öncesi değerlendirmede hastaya özel sorunlar ele alınmalıdır. Yeniden osteosentez ya da osteotomi girişimi planlanıyorsa tütün kullanımı varsa kesilmelidir. Ayrıca, özellikle yaşlı ve güçten düşmüş hastalarda hem tıbbi hem de beslenme durumunun daha iyi hale getirilmesi de genel başarı için kritik öneme sahiptir. ${ }^{8]}$

Altmış yaşın altındaki hastalarda kalça eklemini korumak için femur başının korunması tercih edilen kurtarma tedavisidir (Şekil 1). Bu, kırık bölgesindeki mekanik ortamın iyileştirilmesini (yani valgus
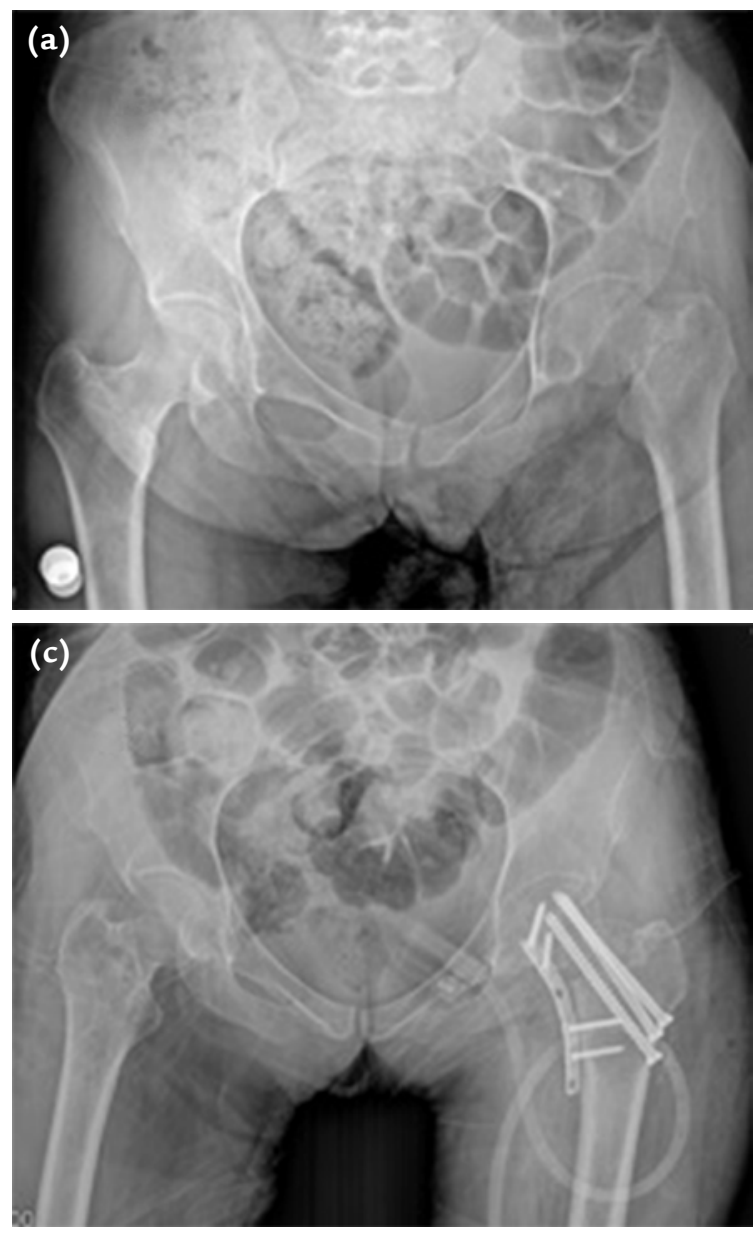

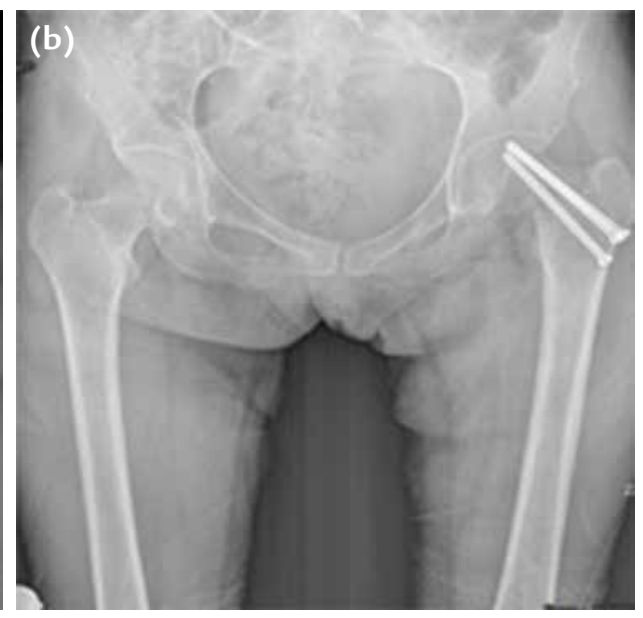

Şekil 1. a-c. Kırk dört yaşında sol femur boyun kırığına sahip erkek hasta. Sol femur boyun kırığını gösteren ön arka pelvis grafisi (a). Kapalı redüksiyon internal tespit uygulanan hastanın ameliyat sonrası görüntüsü (b). Hastaya taburculuk öncesi revizyon osteosentez uygulandı (açık redüksiyon internal tespitte kanüllü vida tespiti medial destek plak ile güçlendirildi) (c). 
osteotomileri) veya kemik grefti (damarlı olmayan, serbest damarlı veya kas pedikülü tipi greftler) ile kaynamama bölgesinin biyolojik ortamının iyileştirilmesini içerebilir. ${ }^{[9,10]}$ Ancak yine de uygun tedavi birçok faktöre bağlıdır. Yaş, hastanın genel durumu, femur başının canlılığı, boyundaki kemik kaybı (rezorpsiyon) miktarı ve kaynamama oluşma zamanı bu faktörlerdendir. Proksimal femur kaynamama olgularının çoğunun 60 yaş üzeri olması cerrahi açıdan yetersiz sonuçlar elde edilmesinde rol alır. İleri derecede osteoporoz internal tespitin etkinliğini azaltır. ${ }^{[11]}$

Femur boyun kırıklarında tespit yetersizliği ve kaynamama için önerilen ameliyatlar genel olarak dört grupta ele alınabilir. 1) Yeniden osteosentez ve/veya greftleme, 2) valgus osteotomisi, 3) artroplasti (hemiartroplasti/total kalça artroplastisi) ve 4) artrodez. ${ }^{[1,2,12]}$

Tercih edilecek cerrahi yöntem için genel prensipler aşağıda özetlenmiştir ${ }^{[1,2,12]}$ :

1- Altmış yaş altı kaynamamış femur boyun kırıklarında femur başı canlıysa yeniden osteosentez ya da osteotomilerle tedavi edilebilir.

2- Çocuklarda ve 21 yaş altı genç erişkinlerde femur başı canlı değilse artrodez yapılabilir. Sıra dışı durumlarda genç erişkinler protez ile tedavi edilebilirler.

3- Yirmi bir ile altmış yaş arası erişkinlerde femur başı canlı değilse cerrahın tecrübesine ve hastanın durumuna göre total kalça artroplastisi veya artrodez seçeneklerinden biri tercih edilebilir.

4- Altmış yaş üzeri kaynamama olan hastalarda femur başı canlılığına bakılmaksızın hemiartroplasti ya da total kalça artroplasitisi uygulanır.

5- Eğer enfeksiyona ait bir işaret varsa, ilk aşamada enfeksiyonun ortadan kaldırılması ve daha sonraki aşamada artroplasti yapılması düşünülebilir.

\section{TEDAVI SEÇENEKLERi}

\section{Yeniden Osteosentez ve/veya Greftleme}

Bu konuda bir fikir birliği yoktur. Genellikle ilk üç hafta içince oluşan yetersiz tespitlerde yeniden osteosentez denenebilir. Yeniden tespit teknik kuralları taze kırıklarda olduğu gibidir. ${ }^{[2,12]}$ Kaynamama bölgesinde biyolojik ortamı iyileştirmek amacıyla kemik grefti kullanılabilir. En yaygın olarak çalışılan greft, ilk olarak Judet tarafından tanımlanan ve daha sonra Meyers ve ark. tarafindan modifiye edilen quadratus femoris damarlı pedikül greftidir. ${ }^{[13]}$ LeCroy ve ark., 50 yaşın altındaki hastalarda femur boyun kaynamamasının tedavisi olarak serbest damarlı fibular greftleme kullanarak sonuçlarını bildirmişlerdir. Kaynamama olgusundan 22 hastanın 20'si (\%91) yaklaşık 10 aylık ortalama kaynama süresi ile iyileşmiştir. Ancak, takiplerde 13 hastada femur başı osteonekrozu meydana gelmiştir. ${ }^{[10]}$ ihmal edilmiş kırık, başarısız osteosentez veya osteonekrozlu kaynamama olan hastalarda, kemik grefti yöntemlerini değerlendiren birçok başka çalışma da bulunmaktadır. Bununla birlikte, mevcut literatür herhangi bir tekniğin üstünlügünü desteklememektedir. ${ }^{[14-16]}$

\section{Proksimal Femoral Osteotomi}

Genç hastalarda, internal tespitin kaybolduğu, başın varusa gittiği, ancak baş canlılığının iyi olduğu durumlarda en iyi seçenek proksimal femur valgus osteotomisidir $^{[7]}$. Valgus osteotomisi ile vertikal olan kırık hattı biraz daha horizontal hale getirilerek, kırık uçları arasına kompresif kuvvetlerin etki etmesi sağlanır. Normalde, tespit yetmezliğinde varus pozisyonu olur ve bu durumda kırık hattına makaslama kuvvetleri etki eder. Makaslama kuvvetleri kırık uçlarını sürekli ayırmaya çaIışır ve aynı zamanda implant yetmezliği riskini artırır. ${ }^{[7]}$

Proksimal femoral kama eksizyonu ve valgus osteotomisi, ilk kez Prof. Pauwels tarafından 1927'de tanımlanmıştır. ${ }^{[17]}$ Kendisi, çok sayıda komplike femur boyun kaynama yokluğunu kendi tanımladığı osteotomi yöntemiyle ve zamanın ilkel diyebileceğimiz tespit araçları (serklaj teli, basit çivi, gövde alçısı vb.) ile kaynatmayı ve uzun yıllar faal bir kalçanın elde edilmesini sağlamıştır. ${ }^{[17]}$ Günümüzde ise femur boyun kırı̆̆ kaynamamaları tedavisinde iki tip osteotomi ve modifikasyonu kullanılır: Mc Murrey'in "Deplasman osteotomisi” sadece küçük trokanterin proksimaline yapılır. Schanz'ın "Angulasyon osteotomisi” küçük trokanterden veya distalinden yapılır. ${ }^{[1]}$

Süreç içerisinde, tespit için bir müddet sabit açılı kamalı plak kullanılmıştır. Sabit açılı plaklar, osteotomi sonrası çok iyi bir stabilite sağlamaktadır. Açılı plak tespitine ek olarak bir lag (çektirme) vidası, kompresyon yapmak ve ek vida rotasyonel tespit sağlamak için eklenebilir. ${ }^{[18]}$ Günümüzde ise, bu tip plaklar piyasada bulunmamaktadır. Diğer alternatif implantlar ise, kayıcı kalça vidası ve kilitli proksimal femur plaklarıdır. Son yıllarda, bu tip osteotomilerin tespiti için yeni nesil paslanmaz çelik kilitli plaklar üretilmeye başlanmıştır. Bu tip anatomik plaklar ile, femur başına aynı anda çok sayıda kilitli (açısal stabil) vidalar konabilmektedir. Aynı zamanda kompresyona izin veren lag vidaları da sisteme eklenebilmektedir. Yine de, osteotomi ameliyatları teknik olarak zordur ve iyi bir hazırlık gerektirir. ${ }^{[18]}$

\section{Protez Replasman Tedavisi}

Kalça artroplastisi (ister hemiartroplasti ister total kalça artroplastisi), yaşlı hastalarda femur boynu kırığı kaynamaması için ana kurtarma seçeneğidir. ${ }^{[19]}$ Hemiartroplastinin avantajı, daha az komplike olması ve muhtemelen daha düşük bir instabilite riskine sahip 
olmasıdır. Asetabulum eklem kıkırdağında artroz veya implant penetrasyonu nedeniyle önemli ölçüde erozyon varsa, hastanın yaşı genç ve fonksiyonel kapasitesi yüksekse total kalça artroplastisi tercih edilen seçenektir. Hasta yaşı, ek hastalıkları, ameliyat öncesi radyografilerin incelenmesi ve asetabular kıkırdağın ameliyat içi muayenesi tercih edilecek yönteme karar vermede rehberlik edecektir. Hemiartroplasti planlanıyorsa da, ameliyatta total kalça artroplastisi bileşenlerine sahip olmak akıllıca olacaktır. ${ }^{[19]}$ Endikasyonlarda hala kesin sınırlar belirlenmemiştir. Protez genellikle 60 yaş üstü hastalarda tercih edilmelidir, 60 yaş altında ise geçerli sebep varlığında uygulanır. Günümüzde protez uygulamaları komplikasyon tedavilerinden daha sık akut kırık tedavilerinde uygulanır olmuştur. Bununla birlikte 60 yaş altındaki femur başı canlı olmayan hastalarda kaynama olsun veya olmasın protez replasman tedavisi yapılabilir. ${ }^{[20]}$

Başarısız internal tespit sonrası total kalça artroplastisi planlandığında dikkate alınması gereken birkaç önemli teknik konu vardır. ${ }^{[2]}$ Orijinal donanımın çıkarılmasıyla femoral şaftta (cisimde) artakalan kemik defekti olacaktır. Tipik olarak standart femoral bileşenler kullanılırsa da, bu proksimal kusurlar kanal hazırlığı sırasında ameliyat içi kırık riski oluşturabilir. Asetabulum ile ilgili olarak ise, kullanılmamaya bağlı osteopeni nedeniyle asetabular kemik kalitesi genellikle çok kötüdür. Ayrıca, bu hastaların çoğunda dejeneratif kalça artrozu olmadığından, elektif total kalça artroplastisi geçiren dejeneratif artrozlu hastalarda mevcut olan sklerotik subkondral kemiğe sahip değildirler. ${ }^{[2]} \mathrm{Bu}$ nedenle, çimentosuz bir asetabular bileşenin yerleştirilmesi, zayıf press-fit tespit nedeniyle zor olabilir. Asetabular oyma, subkondral kemiği korumaya çalışarak dikkatlice yapılmalıdır; kurvetli asetabular komponent impaksiyonundan kaçınılmalı ve vidalarla komponent sabitlemesi artırılmalıdır. ${ }^{[2]}$

Literatür, proksimal femur kırıklarında başarısız osteosentez sonrası uygulanan kalça artroplastisinin, birincil uygulananlara göre fonksiyonel sonuçlarının daha kötü, sağkalımın daha kısa ve komplikasyon (özellikle dislokasyon ve enfeksiyon) oranlarının daha yüksek olduğunu işaret etmektedir. ${ }^{[21-24]}$ McKinley ve Robinson ${ }^{[23]}$, kurtarma artroplastisini birincil total kalça artroplastisi ile karşılaştırdıkları 214 hastalık çalışmada kurtarma artroplasti grubunda birincil artroplasti grubuna göre önemli ölçüde daha yüksek bir çıkık oranı (\%21'e karşı \%8) ve daha fazla yüzeyel enfeksiyon bildirmişlerdir. Ayrıca, kurtarma grubunda fonksiyonel skor ve implant sağkalımının daha düşük olduğu görülmüştür (Şekil 2).
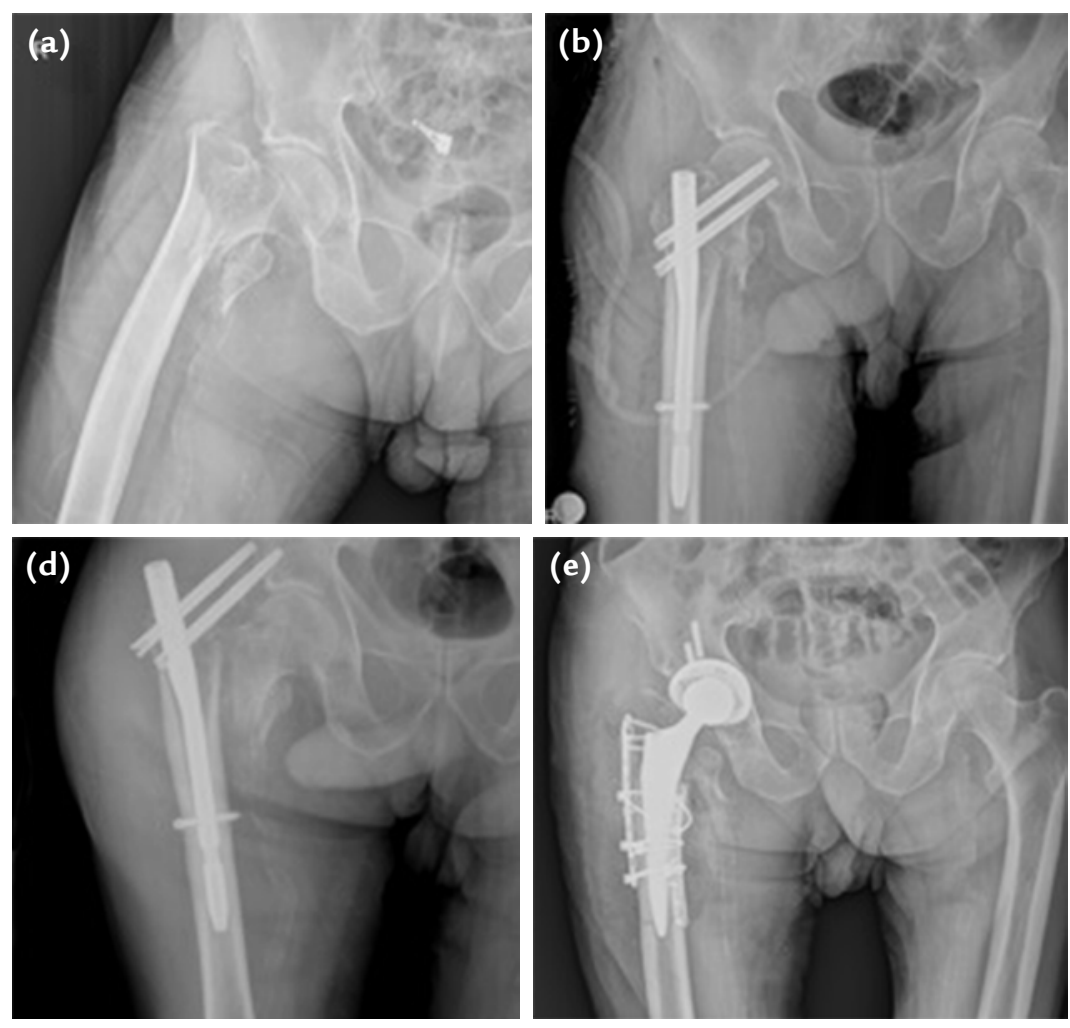

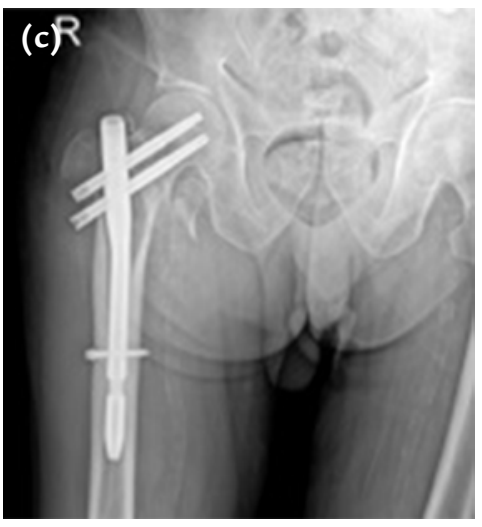

Şekil 2. a-e. Altmış yedi yaşında sağ femur intertrokanterik kırığa sahip erkek hasta (a). Hastaya proksimal femur çivisi ile kapalı redüksiyon internal tespit yapıldı (b). Hastanın ameliyat sonrası ön arka pelvis grafisi (c). Hastanın takip grafilerinde redüksiyon kaybı görüntüleri (d). Kurtarma seçeneği olarak total kalça artroplastisi tercih edildi. Ameliyat içi femur kırığı gelişmesi üzerine plak ile tespit uygulandı (e). 

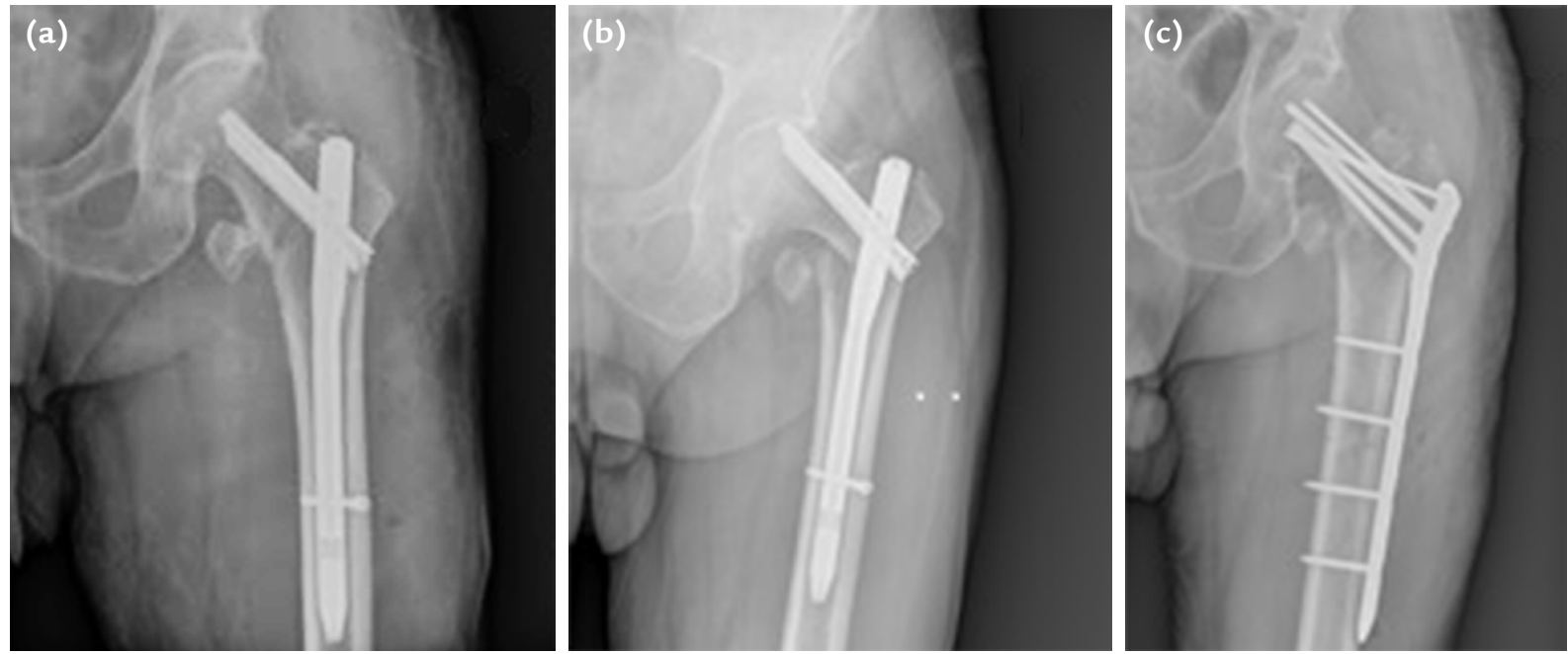

Şekil 3. a-c. Elli altı yaşında sol femur intertrokanterik kırığa sahip erkek hasta. Proksimal femur çivisi ile kapalı redüksiyon internal tespit yapılan hastanın ameliyat sonrası ön arka pelvis grafisi (a). Hastanın birinci ay takip grafısinde redüksiyon kaybı görüntüsü (b). Kurtarma seçeneği olarak plak-vida ile revizyon osteosentez uygulandı (c).

\section{Artrodez}

Günümüzde nadir tercih edilen bir yöntemdir. Gill'e göre ağrıdan kurtulma ve ağırlık altında daha stabil durma sonucu daha kullanılışlı bir uzuv elde edilmesi artrodezin avantajlarındandır. Ağır beden gücüne dayaIı iş yapan, 50 yaş altı erişkin hastalarda önerilebilir. ${ }^{[25]}$

\section{FEMUR INTERTROKANTERIK KIRIKLARDA TESPIT YETERSIZLIĞi}

Modern cerrahi teknik ve tespit cihazları ile intertrokanterik kırıkların çoğu başarılı bir şekilde tedavi edilebilir. Intertrokanterik kırıkları olan hastalarda kaynamama sıklığ, ilk tedaviye bakılmaksızın \%1-2 olarak bildirilmektedir. Kaynamama nadirdir çünkü bu kırıklar iyi damarlanmış süngersi kemik sahasında görülür. Bununla birlikte, genellikle kötü kırık paternleri, kötü redüksiyon, zayıf kemik kalitesi, uygun olmayan implant seçimi veya implant konumu nedeni ile tespit başarısızlığı veya kaynamama meydana gelebilir. ${ }^{[26]}$ intertrokanterik kırık tespitinin genel olarak başarılı sonuçlarına rağmen, başarısızlık meydana geldiğinde tedavi zordur. Çoğu cerrah, uzun ömür beklentisi olan fizyolojik olarak daha genç hastalar için internal tespitle (revizyon osteosentez veya osteotomi) kurtarmayı tercih eder (Şekil 3). Yaşlı hastalarda ise eklemi korumak için yapılan ameliyatın karmaşıklığı nedeniyle genellikle kalça artroplastisi tercih edilir (Şekil 4). ${ }^{[27-29]}$

Said ve ark., intertrokanterik kırık nedeni ile dinamik kalça vidası uygulanan, ancak başarısız olunan 26 hastadan oluşan bir olgu serisi yayımlamışlardır. ${ }^{[30]}$
On sekiz hasta revizyon internal tespit ve sekiz hasta protez replasmanı ile tedavi edilmiştir. Revizyon internal tespitte, sekiz hastada dinamik kalça vidası tekrar yerleştirilip, altı hastada dinamik kalça vidası ile valgus osteotomisi uygulanmış ve dört hastada $130^{\circ}$ 'lik kamalı plak ve valgus osteotomisi uygulanmıştır. Protez replasman grubunda beş hastada çimentolu hemiartroplasti ve üç hastada çimentolu total kalça artroplastisi uygulanmıştır. Revizyon internal tespit grubundaki tüm hastalarda, kemik grefti olmadan, ortalama 17 hafta kaynama süresi ile kırık iyileşmesi sağlanmıştır. Kamalı plak tespiti uygulanan bir hastada femur başı avasküler nekrozu geliştiği görülmüştür. Protez replasman grubundaki sekiz hastadan altısı iyi bir fonksiyonel sonuç ve ağrısız yürüyüş elde etmiş; kalan ikisinin tatmin edici olmayan sonuçlara sahip olduğu görülmüştür. Bu çalışma, kemik stoğu iyi olan fizyolojik olarak daha genç hastalar için revizyon internal tespit ile kaynamanın sağlanabileceğini göstermiştir. Aynı zamanda aktivite düzeyi düşük, kötü kemik kalitesi olan veya hasarlı kalça eklem yüzeyine sahip yaşlı hastalarda kalça artroplastisinin başarılı bir tedavi yöntemi olduğu görülmüştür. ${ }^{[30]}$

\section{SONUÇ}

Genç hastalarda proksimal femur kaynamamalarının tedavisi kalça eklemini internal tespit ile koruma çabalarını içerir. Çoğu yaşı hastada protez replasmanı güvenilir bir kurtarma seçeneğidir. Karar vermeyi etkileyen faktörler arasında kaynamamanın yeri, hastanın fizyolojik yaşı, kalan proksimal kemik stoğunun 

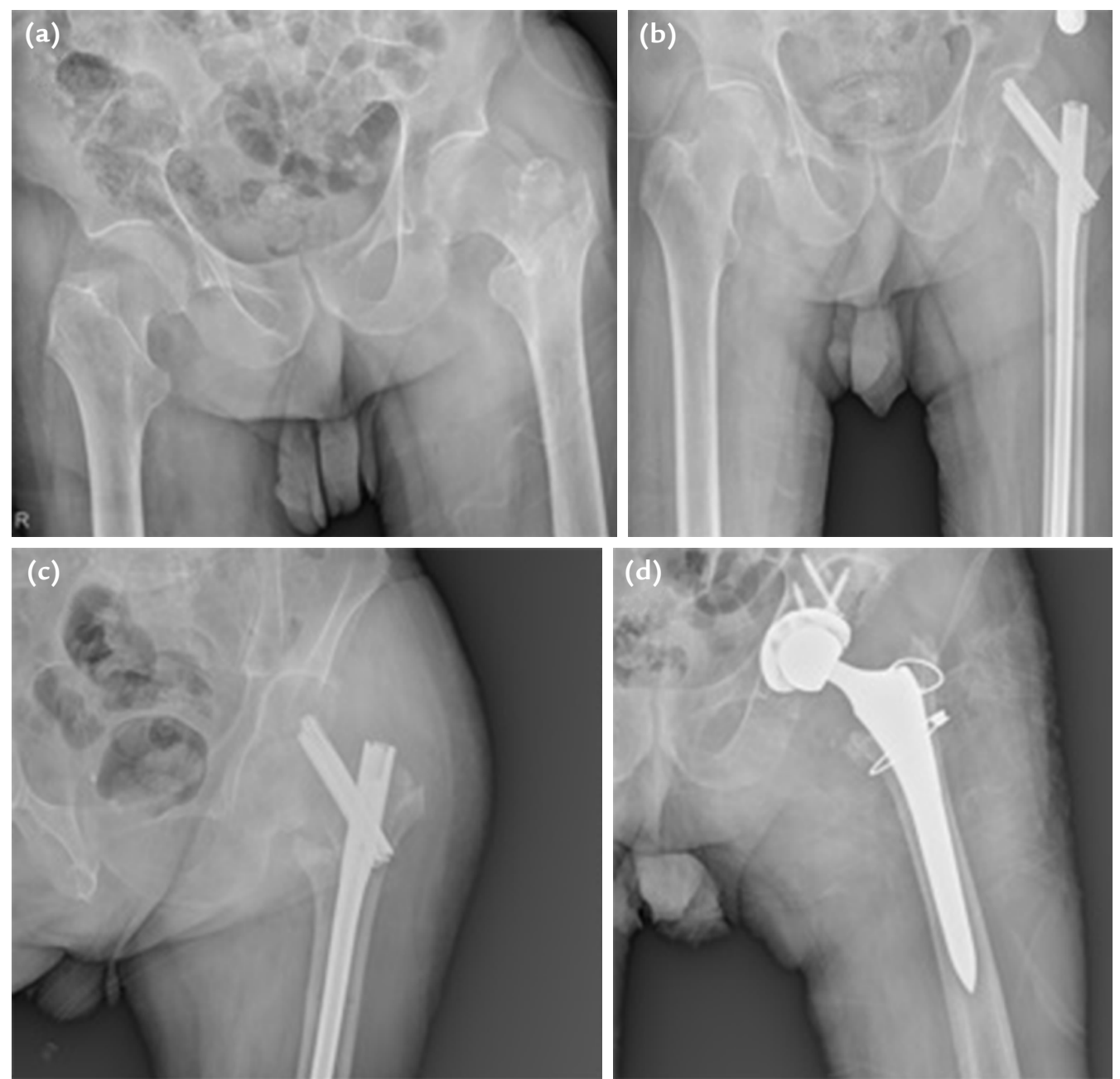

Şekil 4. a-d. Altmış beş yaşında sol femur intertrokanterik kırı̆ga sahip erkek hasta. Sol femur intertrokanterik kırığı gösteren ön arka pelvis grafisi (a). Proksimal femur çivisi ile kapalı redüksiyon internal tespit yapılan hastanın ameliyat sonrası ön arka pelvis grafisi (b). Hastanın üçüncü ay takip grafisindeki redüksiyon kaybı görüntüsü (c). Kurtarma seçeneği olarak total kalça artroplastisi uygulandı (d).

kalitesi, kalça ekleminin durumu ve femur başının canIılığı yer alır. Seçilen kurtarma yönteminden bağımsız olarak, belirli teknik ayrıntılara dikkat edilmesi başarı oranını artırabilir ve bu zorlu sorunları tedavi etmenin zorluklarını azaltabilir.

\section{KAYNAKLAR}

1. Lavelle DG. Fractures and dislocations of the hip. In: Azar F, Canale ST, Beaty J, editors. Campbell's Operative Orthopaedics, 13th ed. Elsevier Inc: 2016. p.2817-64.

2. Angelini M, McKee MD, Waddell JP, Haidukewych G, Schemitsch EH. Salvage of failed hip fracture fixation. J Orthop Trauma 2009;23(6):471-8. Crossref

3. Petrie J, Sassoon A, Haidukewych GJ. When femoral fracture fixation fails: salvage options. Bone Joint J 2013;95-B(11):710. Crossref
4. Kyle RF, Cabanela ME, Russell TA, Swiontkowski MF, Winquist RA, Zuckerman JD, Schmidt AH, Koval KJ. Fractures of the proximal part of the femur. Instr Course Lect 1995;44:22753. https://pubmed.ncbi.nlm.nih.gov/7797861/

5. Parker MJ. Prediction of fracture union after internal fixation of intracapsular femoral neck fractures. Injury 1994;25(Suppl 2):SB3-6. Crossref

6. Slobogean GP, Sprague SA, Scott T, Bhandari M. Complications following young femoral neck fractures. Injury 2015;46(3):484-91. Crossref

7. Keating JF. Femoral neck fractures. In: Court-Brown CM, Heckman JD, McQuenn MM, Ricci WM, Tornetta P $3 r d$, editors. Rockwood and Green's Fractures in Adults, Philadelphia PA: Wolters Kluwer Health; 2015. p.2031-75.

8. Haidukewych GJ, Berry DJ. Salvage of failed treatment of hip fractures. J Am Acad Orthop Surg 2005;13(2):101-9. Crossref 
9. Alho A, Benterud JG, Solovieva S. Internally fixed femoral neck fractures: early prediction of failure in 203 elderly patients with displaced fractures. Acta Orthop Scand 1999;70(2):141-4. Crossref

10. LeCroy CM, Rizzo M, Gunneson EE, Urbaniak JR. Free vascularized fibular bone grafting in the management of femoral neck nonunion in patients younger than fifty years. J Orthop Trauma 2002;16(7):464-72. Crossref

11. D’Arrigo C, Perugia D, Carcangiu A, Monaco E, Speranza A, Ferretti A. Hip arthroplasty for failed treatment of proximal femoral fractures. Int Orthop 2010;34(7):939-42. Crossref

12. Arazi M. Complications of internally fixed femoral neck fractures. TOTBID Derg 2017;16(6):557-61. Crossref

13. Meyers MH, Harvey JP, Moore TM. Treatment of displaced subcapital and transcervical fractures of the femoral neck by muscle-pedicle-bone graft and internal fixation. J Bone Joint Surg Am 1973;55(2):257-74. Crossref

14. Nagi ON, Dhillon MS, Goni VG. Open reduction, internal fixation and fibular autografting for neglected fracture of the femoral neck. J Bone Joint Surg Br 1998;80-B(5):798-804. Crossref

15. Hou SM, Hang YS, Liu TK. Ununited femoral neck fractures by open reduction and vascularized iliac bone graft. Clin Orthop Relat Res 1993;294:176-80. Crossref

16. Bonfiglio M, Yoke EM. Aseptic necrosis of the femoral head and nonunion of the femoral neck. J Bone Joint Surg Am 1968;50(1):48-66. Crossref

17. Pauwels F. Biomechanics of the Normal and Diseased Hip: Theoretical Foundation, Technique and Results of Treatment. An Atlas. Berlin: Springer Verlag; 1976. p.1-37. Crossref

18. Khan AQ, Khan MS, Sherwani MKA, Agarwal R. Role of valgus osteotomy and fixation with dynamic hip screw and $120^{\circ}$ double angle barrel plate in the management of neglected and ununited femoral neck fracture in young patients. J Orthop Traumatol 2009;10(2):71-8. Crossref

19. Hammad A, Abdel-Aal A, Said HG, Bakr H. Total hip arthroplasty following failure of dynamic hip screw fixation of fractures of the proximal femur. Acta Orthop Belg 2008;74(6):788-92. https://pubmed.ncbi.nlm.nih. gov/19205326/
20. Archibeck MJ, Carothers JT, Tripuraneni KR, White RE. Total hip arthroplasty after failed internal fixation of proximal femoral fractures. J Arthroplasty 2013;28(1):168-71. Crossref

21. Franzen $H$, Nilsson $L T$, Stromqvist $B$, Johnsson R, Herrlin K. Secondary total hip replacement after fractures of the femoral neck. J Bone Joint Surg Br 1990;72-B(5):784-7. Crossref

22. Hagglund G, Nordstrom B, Lidgren L. Total hip replacement after nailing failure in femoral neck fractures. Arch Orthop Trauma Surg 1984;103(2):125-7. Crossref

23. McKinley JC, Robinson CM. Treatment of displaced intracapsular hip fractures with total hip arthroplasty: comparison of primary arthroplasty with early salvage arthroplasty after failed internal fixation. J Bone Joint Surg Am 2002;84(11):2010-5. Crossref

24. Turner A, Wroblewski BM. Charnley low-friction arthroplasty for the treatment of hips with late complications of femoral neck fractures. Clin Orthop Relat Res 1984;(185):126-30. Crossref

25. Gill $A B$. Arthrodesis of the hip of ununited fractures. J Bone Joint Surg Am 1947;29(2):305-9. https://pubmed.ncbi.nlm. nih.gov/20240187/

26. BW Min, KJ Lee, JK Oh, CH Cho, JW Cho, BS Kim. The Treatment Strategies for Failed Fixation of Intertrochanteric Fractures. Injury 2019;50(7):1339-46. Crossref

27. Morice A, Ducellier F, Bizot P; Orthopaedics and Traumatology Society of Western France. Total hip arthroplasty after failed fixation of a proximal femurfracture: Analysis of 59 cases of intra- and extra-capsular fractures. Orthop Traumatol Surg Res 2018;104(5):681-6. Crossref

28. DeHaan AM, Groat T, Priddy M, Ellis TJ, Duwelius PJ, Friess DM, Mirza AJ. Salvage hip arthroplasty after failed fixation of proximal femur fractures. J Arthroplasty 2013;28(5):855-9. Crossref

29. Leonard M, Alao U, Glynn A, Dolan M. Hip fractures: failure of fixation and outcome of salvage arthroplasty. Eur J Orthop Surg Traumatol 2009;19(8):553-8. Crossref

30. Said GZ, Farouk O, El-Sayed A, Said HG. Salvage of failed dynamic hip screw fixation of intertrochanteric fractures. Injury 2006;37(2):194-202. [Erratum in: Injury 2006;37(6):577-9. https://doi.org/10.1016/j.injury.2006.02.013] Crossref 